\title{
Rancangan Konversi Kredit Konsumtif menjadi Akad Murabahah pada Koperasi Warga Cipta Mas 2
}

\author{
The plan for converting a consumptive credit into a murabahah agreement at the Cipta Mas \\ Citizen Cooperative 2
}

\section{Fariza Bahari Fadliani}

Program Studi D4 Keuangan Syariah, Politeknik Negeri Bandung

E-mail: farizabahari.ksy15@polban.ac.id

\section{Djoni Djatnika}

Jurusan Akuntansi, Politeknik Negeri Bandung

E-mail: djoni.djatnika@polban.ac.id

\section{Kritianingsih}

Jurusan Akuntansi, Politeknik Negeri Bandung

E-mail: kristianingsih@polban.ac.id

\begin{abstract}
The emergence of sharia cooperatives is the improvement of conventional cooperatives that are not in line with the sharia principles one of them is riba. The Sharia-economic spirit was also felt by members and managers of the Koperasi Warga Cipta Mas 2 located in Bandung Barat. The adjustment of this report primarily lies in the use of the agreement that must comply with the sharia principles that are stored in the postal gathering funds and the disbursement of funds. Adjustments are also made to the source of cooperative income that should not be derived from riba and the use of fines that should not be recognized as cooperative income. Then followed by the design of the Murabahah receivables that can be used when the Koperasi Warga Cipta Mas 2 has become a cooperative sharia. The selection of the agreement is based on the history of borrowing and the needs of members who are mostly loans for personal consumption. In this draft, the procedure was obtained for the application of Murabahah financing, installment financing, and handling problematic financing.
\end{abstract}

Keywords: sharia cooperative, sharia cooperative conversion, murabahah, financial report

\section{Pendahuluan}

Menurut data statistik koperasi simpan pinjam 2016 oleh Badan Pusat Statistik perkembangan koperasi yang menggunakan sistem bagi hasil (syariah) terus mengalami peningkatan, yaitu pada tahun 2016 sebesar 20,34\% dari total koperasi yang terdapat di Indonesia, meningkat sebesar $8,21 \%$ dari jumlah koperasi simpan pinjam yang menggunakan sistem bagi hasil pada tahun 2013 (BPS, 2017). Berikut adalah data presentase penyebaran koperasi yang menggunakan prinsip syariah dan konvensional di Pulau Jawa tahun 2016 (berdasarkan jumlah unit koperasi di Indonesia Tahun 2016 yaitu sebanyak 150.223 unit): 
Tabel 1. Presentase Koperasi Simpan Pinjam Menurut Sistem Pengembalian Pinjaman Tahun 2016

\begin{tabular}{|l|c|c|c|}
\hline \multirow{2}{*}{ Provinsi } & \multicolumn{2}{|c|}{ Sistem Pengembalian Pinjaman } & \multirow{2}{*}{ Jumlah } \\
\cline { 2 - 3 } & Bagi Hasil & Konvensional & \\
\hline DKI Jakarta & 0,29 & 0,58 & 0,87 \\
\hline Jawa Barat & 1,64 & 4,70 & 6,34 \\
\hline Jawa Tengah & 4,12 & 19,84 & 23,96 \\
\hline Daerah Istimewa Yogyakarta & 0,18 & 1,61 & 1,80 \\
\hline Jawa Timur & 5,60 & 24,75 & 30,35 \\
\hline Banten & 0,34 & 0,90 & 1,24 \\
\hline
\end{tabular}

Sumber: wnw.bps.go.id (data diolah kembali)

Kesadaran dalam keinginan untuk menerapkan syariat-syariat Islam pada sistem operasinya juga sedang dialami oleh Koperasi Warga Cipta Mas 2 yang terletak di Desa Laksanamekar, Padalarang, Kabupaten Bandung Barat. Koperasi yang didirikan pada tahun 2002 ini merupakan koperasi yang dijalankan berdasarkan sistem konvensional dengan bidang usaha jasa dan simpan pinjam.

Pada awal bulan September 2018, telah dilaksanakan rapat rutin pengurus koperasi yang kemudian menjadi dasar keinginan pengurus untuk berhijrah dari sistem konvensional menjadi sistem syariah. Kemudian ditindak lanjuti oleh para pengurus dengan melakukan studi lapangan berkunjung ke BMT Maddani, yaitu koperasi syariah yang terletak di kawasan Lembang. Studi lapangan ini dijadikan dasar ilmu mengenai prinsip syariah dan dasar menjalankan koperasi dengan sistem syariah. Selanjutnya pengurus melaksanakan sosialisasi pertama kepada para anggota koperasi dengan tema "Urgensi Menjalani Usaha Sesuai Syariah" yang telah dilaksanakan pada tanggal 30 September 2018. Sosialisasi ini berkaitan dengan pemahaman mengenai pentingnya menjalankan aktivitas ekonomi sesuai dengan prinsip syariah yang menekankan pada bahaya penggunaan riba pada kehidupan sehari-hari. Anggota koperasi yang hadir pada sosialisasi tersebut berjumlah 102 orang (Dokumen internal Koperasi Warga Cipta Mas 2, 2018).

Berdasarkan hasil survei yang dilakukan didapatkan data bahwa dari 102 peserta yang hadir pada sosialisasi pertama anggota Koperasi Warga Cipta Mas 2 dengan tema "Urgensi Menjalani Usaha Sesuai Syariah", 98 peserta menyatakan bahwa bunga riba yang dijalankan oleh koperasi konvensional hukumnya adalah haram, hal ini dapat diinterpretasikan bahwa sebagian besar anggota telah memahami konsep mengenai keharaman riba yang telah disosialisasikan. Pada pertanyaan tentang pengetahuan mengenai koperasi syariah, 78 peserta menyatakan sangat paham sedangkan sisanya kurang memahami dan 4 orang tidak paham. Pengetahuan yang dimaksud adalah konsep pengertian sederhana dan akad-akad yang digunakan dalam bertransaksi. Hal ini menunjukkan bahwa setelah sosialisasi pertama anggota koperasi mayoritas memahami materi koperasi syariah yang telah disampaikan. Pada pertanyaan mengenai urgensi konversi Koperasi Warga Cipta Mas 2, 96 peserta menjawab bahwa hal tersebut adalah sangat wajib untuk dilakukan dan 100 peserta menyatakan bahwa mereka menginginkan agar Koperasi Warga Cipta Mas 2 berhijrah untuk menggunakan sistem operasional berbasis syariah. Dari penjelasan tersebut dapat disimpulkan bahwa mayoritas anggota Koperasi Warga Cipta Mas 2 menginginkan untuk merubah sistem koperasinya menjadi berbasis syariah.

Koperasi Warga Cipta Mas 2 perlu mempertimbangkan hal-hal yang menjadi syarat perubahan sistem dari konvensional menjadi syariah. Sesuai dengan peraturan Menteri Koperasi dan UMKM, terdapat dua aspek penting yang harus disesuaikan yaitu aspek manajemen dan aspek prinsip yang terangkum dalam anggaran rumah tangga koperasi. Pada sisi manajemen, laporan keuangan menjadi hal yang diutamakan untuk dilakukan penyesuaiannya. Selanjutnya perbedaan 
yang mendasar ketika koperasi telah beroperasi dengan menggunakan sistem syariah adalah dengan penggunaan sistem pembiayaan yang sesuai fiqh mu'amalah, yaitu salah satunya penggunaan akad murabahah (Ruslan, 2013). Akad murabahah adalah akad jual beli untuk menyalurkan pembiayaan kepada sektor konsumsi, seperti pembelian alat-alat elektronik dan lain-lain. Setelah melakukan konversi menjadi koperasi syariah, dalam kesiapan melaksanakan operasional dirasa perlu adanya rancang bangun mengenai tata cara penggunaan akad murabahah yang dapat diaplikasikan kepada koperasi yang bersangkutan. Rancang konversi akad murabahab ini dipilih dalam penelitian karena berdasarkan kegiatan pembiayaan yang terjadi di koperasi sebelumnya yaitu kebutuhan anggota yang banyak dilakukan adalah untuk memenuhi kebutuhan konsumtif pembelian barang.

Kebutuhan dan keinginan para pengurus dan anggota Koperasi Warga Cipta Mas 2 tersebut untuk konversi menjadi koperasi syariah menjadi dasar fenomena penelitian serta karena belum ada penelitian yang membahas secara analisis mengenai konversi koperasi konvensional menjadi koperasi syariah.

\section{Kajian Pustaka}

\subsection{Akad Murabahah}

Secara bahasa, kata murabahah berasal dari bahasa Arab dengan akar kata ribh yang artinya "keuntungan". Sedangkan secara istilah, menurut Hakim (2012), murabahah merupakan akad jual beli atas barang tertentu, dimana penjual menyebutkan harga jual yang terdiri atas harga pokok barang dan tingkat keuntungan tertentu tas barang, dimana harga jual tersebut disetujui pembeli. Istilah yang hampir sama juga diberikan oleh Hulwati (2009) yang menyatakan bahwa murabahah secara istilah adalah menjual suatu barang dengan harga modal ditambah dengan keuntungan.

Menurut Ibnu Rusy al Maliki dalam Dimayauddin (2008), murabahah adalah jual beli komoditas dengan penjual memberikan informasi kepada pembeli tentang harga pokok pembelian barang dan tingkat keuntungn yang diinginkan. Menurut Antonio (2001) bai' murabahah adalah jual beli barang pada harga asal dengan tambahan keuntungan yang disepakati. Dalam jual beli murabahah, penjual harus memberi tahu harga produk yang dibeli dan menentukan suatu tingkat keuntungan sebagai tambahannya. Sedangkan Menurut Anwar (1991), murabahahadalah menjual suatu barang dengan harga pokok ditambah keuntungan yang disetujui bersama untuk dibayar pada waktu yang ditentukan atau dibayar secara cicilan.

\subsection{Teknis Pelaksanaan Pembiayaan Murabahah pada Koperasi Syariah}

Dijelaskan dalam Panduan Praktis Koperasi Syariah Indonesia bahwa Koperasi Syariah berperan sebagai perantara anggota dan pemasok dalam memenuhi kebutuhan barang konsumtif yang sesuai dengan akad murabahah. Anggota merupakan pihak yang membutuhkan barang yang diakadkan, disyaratkan cakap hukum berkemampuan membayar. Pada konsep akad Murabahah yang harus diperhatikan adalah pada sisi harga jual yang ditawarkan oleh koperasi, uang muka jika diperlukan, jangka waktu dan pembayaran angsuran, ketentuan denda keterlambatan, dan jaminan yang diberikan oleh anggota. Pelaksanaan akad ini dapat digabung dengan akad Wakalah pada pelaksanaannya, yaitu dengan menugaskan kepada anggota dalam pembelian barangnya, kemudian setelah pelaksanaan akad Wakalah barulah dilaksanakan penandatanganan akad Murabahah.

\section{Metode Penelitian}

Jenis penelitian ini adalah penelitian deskriptif kualitatif berdasarkan pendekatan studi kasus. Subjek penelitian dilakukan pada Koperasi Warga Cipta Mas 2 yang berlokasi di kabupaten Bandung Barat. Dengan objek Penelitian berupa laporan keuangan beserta skema transaksi kredit konsuntif. Peneliti akan mendeskripsikan hasil temuannya dengan mengumpulkan dan memproses laporan keuangan Koperasi Warga Cipta Mas 2 yang semula berbasis konvensional dikonversikan 
menjadi laporan keuangan berbasis syariah. Laporan keuangan yang dimaksud hanya terbatas laporan laba rugi dan neraca. Selain laporan keuangan, rancangan konversi dilakukan pula terhadap skema kredit konsumtif yang telah berjalan di Koperasi Warga Cipta Mas 2. Konversi kredit dilakukan menjadi skema pembiayaan murabahah.

\section{Hasil dan Pembahasan}

\subsection{Penyesuaian Laporan Neraca}

Komponen akun pada aktiva koperasi keuangan yang harus disesuaikan agar sesuai dengan Koperasi Syariah yaitu :

Tabel 1. Penyesuaian Akun Aktiva menjadi Prinsip Syariah

\begin{tabular}{|l|l|}
\hline $\begin{array}{c}\text { Akun-akun Aktiva Koperasi } \\
\text { Warga Cipta Mas 2 }\end{array}$ & \multicolumn{1}{c|}{ Penyesuaian menjadi Syariah } \\
\hline $\begin{array}{l}\text { 1. Simpanan pada Bank } \\
\text { (Konvensional) }\end{array}$ & $\begin{array}{l}\text { Untuk menghindari adanya pendapatan koperasi yang berasal dari bunga (riba), maka } \\
\text { sebaiknya simpanan pada bank seharusnya disimpan di lembaga Perbankan Syariah. }\end{array}$ \\
\hline 2. Piutang pinjaman anggota & $\begin{array}{l}\text { Pada Koperasi Syariah, piutang maupun pembiayaan yang diberikan kepada anggota } \\
\text { harus berdasarkan akad yang sesuai dengan kaidah muamalah, penyajian akun piutang } \\
\text { dan pembiayaan harus dibedakan berdasarkan akadnya sebagai berikut : } \\
\text { 3. Piutang pinjaman komersial } \\
\text { b. Piutang Murabahah } \\
\text { c. Piutang Istishna } \\
\text { d. Piutang Pendapatan Ijarah } \\
\text { e. Pembiayaan Mudharabah } \\
\text { f. Pembiayaan Musyarakah } \\
\text { g. Aktiva yang diperoleh untuk Ijarah } \\
\text { h. Aktiva Istishna dalam penyelesaian } \\
\text { (disesuaikan dengan produk akad yang akan dijalankan oleh koperasi) }\end{array}$ \\
\hline
\end{tabular}

Sumber : Laporan Kenangan Koperasi Warga Cipta Mas 2 (disesuaikan dan diolah kembali)

Pada sisi passiva, akun-akun yang terdapat pada Koperasi Warga Cipta Mas 2 tidak ada yang melanggar pada prinsip syariah namun ada beberapa akun yang harus disesuaikan untuk ditambah pada sisi passiva yaitu : pengakuan hutang salam dan istishna apabila koperasi mengeluarkan akad tersebut pada produk pembiayaannya. Selain kewajiban dan modal terdapat pos investasi tidak terikat. Investasi tidak terikat adalah dana yang diterima oleh koperasi dengan kriteria koperasi mempunyai hak untuk menggunakan dana dan mencampur dana tersebut dengan dana lainnya, serta keuntungan dibagikan sesuai dengan nisbah bagi hasil yang telah disepakati dengan anggota koperasi. Investasi tidak terikat ini tersedia dalam bentuk simpanan mudharabah. Pada koperasi syariah simpanan dana masyarakat menggunakan akad al-wadiah yaitu titipan anggota koperasi yang harus dijaga dan dikembalikan pada saat anggota koperasi menghendakinya.

\subsection{Penyesuaian Laporan Laba Rugi}

Komponen akun pada laba rugi Koperasi Warga Cipta Mas 2 yang harus disesuaikan adalah sebagai berikut : 
Tabel 2 Penyesuaian Laba Rugi menjadi Prinsip Syariah

\begin{tabular}{|c|c|}
\hline $\begin{array}{c}\text { Akun-akun Laba Rugi } \\
\text { Koperasi Warga Cipta Mas } 2\end{array}$ & Akun Penyesuaian Menjadi Syariah \\
\hline $\begin{array}{l}\text { 1. Pendapatan jasa pinjaman } \\
\text { anggota } \\
\text { 2. Pendapatan jasa pinjaman } \\
\text { komersial }\end{array}$ & $\begin{array}{l}\text { Pada koperasi syariah, pendapatan diakui berdasarkan akad pembiayaannya masing- } \\
\text { masing seperti : } \\
\text { 1. Pendapatan margin murabahah } \\
\text { 2. Pendapatan bersih salam paralel } \\
\text { 3. Pendapatan bersih salam istishna } \\
\text { 4. Pendapatan bersih ijarah } \\
\text { 5. Pendapatan bagi hasil mudharabah } \\
\text { 6. Pendapatan bagi hasil musyarakah }\end{array}$ \\
\hline $\begin{array}{l}\text { 3. Pendapatan denda pinjaman } \\
\text { anggota } \\
\text { 4. Pendapatan denda pinjaman } \\
\text { khusus }\end{array}$ & $\begin{array}{l}\text { Pada pembiayaan syariah, denda tidak diakui sebagai pendapatan, melainkan } \\
\text { disalurkan menjadi dana kebajikan yang dapat digunakan untuk menyalurkan } \\
\text { pembiayaan qardh. }\end{array}$ \\
\hline 5. Pendapatan jasa bank & $\begin{array}{l}\text { Apabila penyimpanan dana koperasi telah dipindah ke bank syariah maka dapat diakui } \\
\text { sebagai pendapatan bagi hasil simpanan pada bank (disesuaikan dengan akad yang } \\
\text { disediakan koperasi). }\end{array}$ \\
\hline
\end{tabular}

Sumber: Laporan Kenangan Koperasi Warga Cipta Mas 2 (disesuaikan dan diolah kembali)

\subsection{Rancang Prosedur Akad Murabahah}

Transaksi piutang murabahah yang dapat dijalankan oleh Koperasi Warga Cipta Mas 2 setelah menyesuaikan dengan alur prosedur penyaluran dana yang sebelumnya digunakan berdasarkan SOP operasional koperasi dan diskusi dengan pihak manajemen, maka didapatkan keperluan rumusan rancang prosedur murababah yang harus disesuaikan dengan rangkumannya pada tabel berikut:

Tabel 3. Perbedaan Pelaksanaan Prosedur Sebelum dan Setelah Konversi Menjadi Syariah

\begin{tabular}{|l|l|l|}
\hline \multicolumn{1}{|c|}{ Keterangan } & \multicolumn{1}{|c|}{ Sebelum konversi } & \multicolumn{1}{c|}{ Setelah konversi } \\
\hline Survei Objek Pembiayaan & $\begin{array}{l}\text { Tidak dilakukan survei karena bersifat } \\
\text { meminjamkan uang }\end{array}$ & $\begin{array}{l}\text { Dilakukan survei kepada pemasok untuk mendapatkan } \\
\text { informasi harga perolehan dan ketersediaan barang. }\end{array}$ \\
\hline Ketentuan saldo blokir & $\begin{array}{l}\text { Tidak diberlakukan adanya saldo yang } \\
\text { diblokir }\end{array}$ & $\begin{array}{l}\text { Diberlakukan syarat yakni adanya simpanan aktif berupa } \\
\text { simpanan wadi'ah minimal 2 kali angsuran. }\end{array}$ \\
\hline \hline Tunggakan Kredit & $\begin{array}{l}\text { Tidak ada analisa terkait tunggakan } \\
\text { kredit bermasalah dengan pihak lain }\end{array}$ & $\begin{array}{l}\text { Dilakukan analisa terkait tunggakan kredit bermasalah } \\
\text { dengan pihak lain }\end{array}$ \\
\hline $\begin{array}{l}\text { Pembinaan Pembiayaan } \\
\text { Syariah }\end{array}$ & Tidak ada pembinaan & $\begin{array}{l}\text { Diadakan pembinaan pembiayaan syariah agar anggota } \\
\text { mengerti akad yang digunakan }\end{array}$ \\
\hline $\begin{array}{l}\text { Transparansi harga } \\
\text { perolehan dan margin }\end{array}$ & $\begin{array}{l}\text { Jumlah pokok dan bunga tidak } \\
\text { diberitahukan kepada anggota }\end{array}$ & Harga perolehan dan margin didiskusikan dengan anggota \\
\hline
\end{tabular}




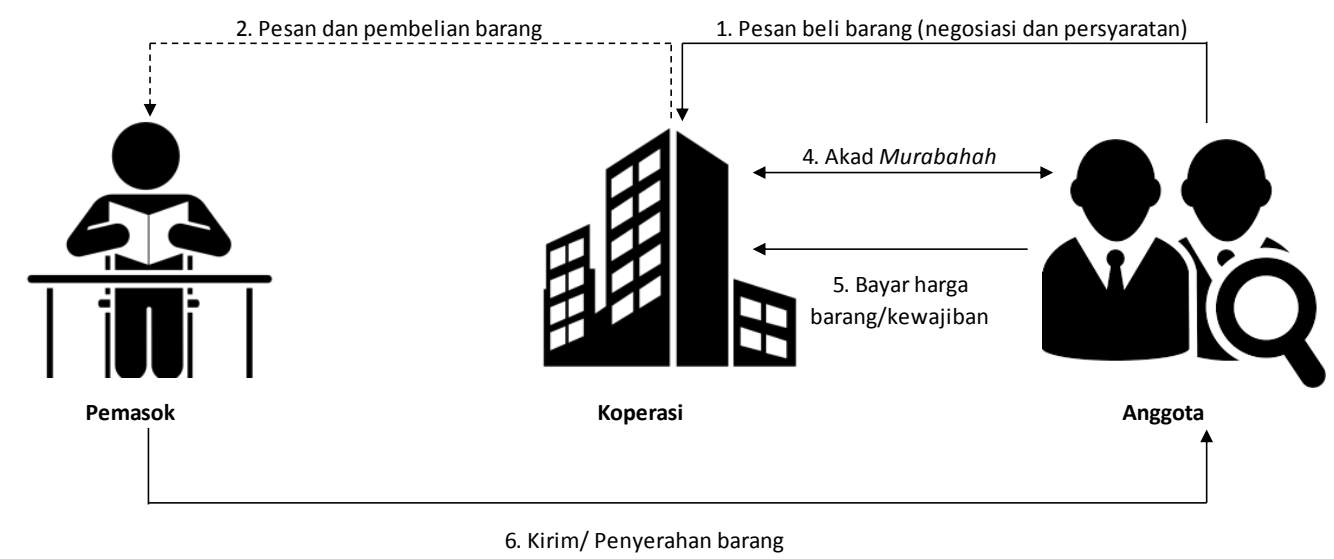

Gambar 1. Alur Murabahah Berdasarkan Pesanan

Pengajuan pembiayaan murabahah pada Koperasi Warga Cipta Mas 2 sesuai alur pada gambar diatas yaitu :

1) Prosedur pertama, anggota datang mengajukan permohonan pembiayaan ke koperasi dengan melengkapi persyaratan-persyaratan.

2) Petugas pembiayaan melakukan pra-analisis pada permohonan anggota tersebut, jika hasilnya pembiayaan tidak dapat dipenuhi/diproses, maka langsung diinformasikan kepada anggota dan bila diperlukan dibuatkan surat penolakan, jika dapat diproses maka dilanjutkan langkahnya sebagai berikut :

a. Analisis pembiayaan yang berkaitan dengan data ekonomis anggota koperasi dan hasil analisis tersebut dimasukkan kedalam memorandum pembiayaan.

b. Melakukan penyidikan kepada pemohon pembiayaan dengan pemeriksaan kelapangan untuk barang jaminan yang akan diserahkan.

c. Melakukan survei objek murabahah dari pemasok seperti harga barang, ketersediaan barang, dan kondisi barang. Survei ini dapat dilakukan ke pemasok yang telah ditunjuk nasabah atau ke pemasok yang menjadi mitra koperasi.

d. Setelah seluruh kelengkapan lengkap dibuatkan proposal pembiayaan dan dilakukan proses keputusan pembiayaan akhir.

3) Analisis pembiayaan yang dilakukan oleh petugas, mempertimbangkan aspek-aspek berikut:

1. Analisis karakter anggota yang akan diberi pembiayaan dengan mempertimbangkan aspek 5C (character, capital, capacity, collateral, dan condition).

2. Analisis ini dibutuhkan dalam menilai apakah anggota mampu membayar pinjaman sampai jatuh tempo yang telah ditetapkan.

4) Komite Pembiayaan

Penentuan disetujui atau tidaknya pembiayaan diputuskan final oleh ketua koperasi setelah mengadakan rapat komite pembiayaan (pada praktiknya biasanya tidak diadakan rapat karena telah mengandalkan proposal pengajuan pembiayaan).

5) Penandatangan akad murabahah dan pencairan pembiayaan

1. Anggota dihubungi oleh pengurus koperasi untuk melakukan penandatangan akad.

2. Petugas pembiayaan menjelaskan kepada anggota mengenai jenis objek murabahah, harga perolehan, margin, angsuran dan jangka waktu pembiayaan. Pada tahap ini, Koperasi Warga Cipta Mas 2 menghendaki adanya tawar-menawar, sehingga besaran margin tidak mutlak dan anggota memiliki hak untuk menawar besaran margin sampai terjadi kesepatan. 
3. Setelah terjadi kesepakatan, petugas pembiayaan akan menghubungi pemasok yang sebelumnya telah disurvei dan melakukan transaksi jual-beli dengan koperasi. Koperasi tidak menghendaki adanya akad wakalah untuk anggota, karena menghendaki prinsip kehati-hatian dalam menerapkan akad murabahab yang sesuai dengan syariah Islam. Pihak koperasi juga melakukan kerja sama dengan pemasok untuk dapat mengirimkan barang yang telah ditransaksikan tersebut kepada anggota pemohon pembiayaan.

4. Akad murabahah yang telah dibuat oleh koperasi kemudian ditandatangani nasabah sebagai tanda telah terjalinnya transaksi murabahah. Selain penandatangan akad juga diproses berkas penandatangan SP3, tanda terima agunan (beserta surat harta asli yang akan dijadikan agunan) dan slip pencairan yang harus ditandatangani pemohon pembiayaan.

5. Pemohon pembiayaan membayar biaya administrasi, notaris (jika diperlukan), dan menyetorkan 2 kali jumlah angsuran pada rekening simpanan wadi'ah. Pengarsipan agunan

6) Angsuran pembiayaan

1. Salah satu cara untuk menetapkan margin dapat dilakukan dengan base lending rate (BLR) yaitu dengan mempertimbangkan biaya penghimpunan dana, ekspektasi bagi hasil, biaya overhead, dan keuntungan yang diharapkan. Penentuan margin ini sama seperti penentuan bunga pada saat koperasi masih menggunakan sistem konvensional, hanya penetapan margin ini akan mempertimbangkan adanya tawar-menawar dengan nasabah sebelum penandatanganan akad, penjelasannya adalah sebagai berikut:

$\begin{array}{lll}\text { Cost of Fund (COF) } & = & \mathrm{x} \\ \text { Overhead Cost }(O H C) & = & \mathrm{x} \\ \text { Risk } & = & \mathrm{x} \\ \text { Spread/Mark Up } & = & \\ \text { BLR } & = & \mathrm{x}\end{array}$

2. Metode perhitungan angsuran pembiayaan

Mempertimbangkan salah satu metode perhitungan angsuran yang digunakan oleh bank syariah terdapat 2 alternatif perhitungan angsuran, yaitu :

a. Formula annuitas

$$
\begin{gathered}
\text { Angsuran }=\frac{\text { plafon } x \frac{\text { pricing }}{12}}{1-\left(1+\frac{\text { pricing }}{12}\right)^{- \text {jangka waktu }}} \\
\text { Margin }=\frac{\text { Outstanding Pokok } k_{n-1} \text { xpricing }}{12} \\
\text { Pokok }=\text { Angsuran }+ \text { Margin } \\
\text { Outstanding Pokok }=\text { Outstanding Pokok } \text { Ou-1 }_{n-1}+\text { Pokok }
\end{gathered}
$$

b. Formula efektif/sliding

7) Penanganan pembiayaan bermasalah

Penanganan pembiayaan bermasalah dilakukan setelah pembiayaan masuk dalam kategori kurang lancar, diragukan, dalam perhatian khusus, dan macet. Penyesuaian langkah-langkah penyelamatan dapat dilakukan dengan cara : 
a. Penjadwalan kembali (Rescheduling)

$$
\begin{gathered}
\text { Pokok }=\frac{\text { plafon }}{\text { Jangka waktu }} \\
\text { Margin }=\frac{\text { Outstanding } \text { Pokok }_{n-1} \text { xpricing }}{12} \\
\text { Angsuran }=\text { Pokok }+ \text { Margin } \\
\text { Outstanding Pokok }=\text { Outstanding } \text { Pokok }_{n-1}+\text { Pokok }
\end{gathered}
$$

b. Persyaratan kembali pembiayaan (Reconditioning)

c. Penataan kembali pembiayaan (Restructuring)

\section{Penutup}

Penyesuaian laporan keuangan pada Koperasi Warga Cipta Mas 2 difokuskan pada penyesuaian laporan neraca dan laba rugi. Pada neraca, penyesuaian yang utama dilihat dari sisi penghimpunan dana dan penyaluran dana. Contoh akad dalam penghimpunan dana yang dapat diterapkan dalam koperasi adalah akad wadi'ah dan mudharabah. Sedangkan pada penyaluran dana akad yang dapat digunakan adalah akad jual beli (murabahah, salam, istishna), akad kerja sama usaha (musyarakah dan mudharabab), dan akad sewa (ijarah dan ijarah muntabiyah bittamlik). Sedangkan pada laporan laba rugi, yang menjadi fokus penyesuaian adalah dari sisi pendapatan. Pendapatan pada koperasi syariah tidak diperkenankan berasal dari usaha yang mengandung riba, seperti denda yang didapatkan karna adanya keterlambatan pembayaran angsuran oleh anggota tidak boleh dianggap sebagai pendapatan koperasi, melainkan dapat disalurkan dalam bentuk dana kebajikan atau pembiayaan qardh.

Pada perancangan transaksi piutang murabahah setelah menyesuaikan dengan alur prosedur penyaluran dana yang sebelumnya berdasarkan SOP operasional koperasi dan diskusi dengan pihak manajemen, maka didapatkan rumusan prosedur permohonan pembiayaan murabahah, pengangsuran pembiayaan dan penanganan pembiayaan bermasalah.

\section{Daftar Pustaka}

Antonio, Muhammad Syafi'i. (2001). Bank Syari'ah; Dari Teori ke Praktik, Jakarta: Gema Insani

Anwar, M. Syafiei. (1991). Alternatif Terhadap Sistem Bunga. Jurnal Ulumul Qur" an II, Edisi 9 Oktober 1991,

BPS. (2017). Statistik Koperasi Simpan Pinjam Indonesia 2016. Jakarta: Badan Pusat Statistik

Djuwaini, Dimyauddin.(2008) Pengantar Fiqih Muamalah, Yogyakarta: Celebsn Timur UH III

Hakim, Lukman. (2012). Prinsip-Prinsip Ekonomi Islam. Yogyakarta: Erlangga

Hulwati. (2009). Ekonomi Islam Teori dan Praktiknya dalam Perdagangan Obligasi Syari'ah di Pasar Modal Indonesia dan Malaysia. Jakarta: Ciputat Press Group

Peraturan Menteri Koperasi dan Usaha Kecil dan Menengah Republik Indonesia Nomor 16 /Per/M.KUKM/IX/2015 tentang Pelaksanaan Kegiatan Usaha Simpan Pinjam Dan Pembiayaan Syariah oleh Koperasi

Ruslan, Murniati. (2013). Sistem Mudarabah dan Aplikasinya pada Bank Syariah Mandiri Cabang Palu. Hunafa: Jurnal Studia Islamika, 10(2), 323-344 